\title{
Efektivitas Strategi REACT (Relating, Experiencing, Applying, Cooperating, Transferring) Terhadap Hasil Belajar Siswa Pada Materi Larutan Penyangga di Kelas XI SMA Negeri 2 Langowan
}

\author{
Zurisaday Taidi ${ }^{* a}$,Ardi Kapahanga, Meiske N. Mamuaja ${ }^{a}$ \\ a Universitas Negeri Manado, Minahasa, 95618, Indonesia
}

\begin{tabular}{l} 
I N F O A R T I K E L \\
\hline Diterima Agustus 19 \\
Disetujui Desember 19 \\
\\
\hline Key word: \\
Buffer Solutions \\
Effectiveness \\
Learning Outcomes \\
REACT \\
\\
\hline Kata kunci: \\
Larutan Penyangga \\
Efektivitas \\
Hasil Belajar \\
REACT \\
\hline
\end{tabular}

\begin{abstract}
A B S T R A C T
Chemistry is a science that studies materials that are generally abstract in nature so many students find it difficult to understand the concept of chemistry which causes a lack of interaction between real life and chemical knowledge. This study aims to determine the effectiveness of the REACT strategy in improving student learning outcomes in buffering material at SMA Negeri 2 Langowan. The research method used is Quasi Experiment Design with research design is Posttest-only Control Group Design. The population is all students of class XI Science in SMA Negeri 2 Langowan even semester 2017/2018. The sample of this study were all students of class XI IPA 1, amounting to 25 people as the experimental class and all students of class XI IPA 2, amounting to 21 people as the control class. Data collected is processed from the results of Posttest. Data were analyzed using the Independent $t$-test formula to test the research hypotheses and obtained tcount> ttable (7.99>2.02), so it can be concluded that the Contextual Teaching and Learning (CTL) learning method with REACT strategy proved to be effective against improving student learning outcomes in buffer material in class XI IPA of SMA Negeri 2 Langowan.
\end{abstract}

\section{A BSTRAK}

Kimia merupakan ilmu sains yang mempelajari materi-materi yang umumnya bersifat abstrak sehingga banyak siswa sulit memahami konsep ilmu kimia yang menyebabkan kurangnya interaksi antara kehidupan nyata dan pengetahuan kimia. Penelitian ini bertujuan untuk mengetahui efektivitas strategi REACT dalam meningkatkan hasil belajar siswa pada materi larutan penyangga di SMA Negeri 2 Langowan. Metode penelitian yang digunakan yaitu Quasi Experiment Design dengan desain penelitian Posttest-only Control Group Design. Populasinya yaitu seluruh siswa kelas XI IPA di SMA Negeri 2 Langowan semester genap tahun ajaran 2017/2018. Sampel penelitian ini adalah seluruh siswa kelas XI IPA 1 yang berjumlah 25 orang sebagai kelas eksperimen dan seluruh siswa kelas XI IPA 2 yang berjumlah 21 orang sebagai kelas kontrol. Data yang dikumpulkan diolah dari hasil Posttest. Data dianalisis dengan menggunakan rumus Independen t-test untuk menguji hipotesis penelitian dan diperoleh thitung $>$ ttabel $(7,99>2,02)$, sehingga dapat disimpulkan bahwa metode pembelajaran Contextual Teaching and Learning (CTL) dengan strategi REACT terbukti efektif terhadap peningkatan hasil belajar siswa pada materi larutan penyangga di kelas XI IPA SMA Negeri 2 Langowan.

\section{Pendahuluan}

Tujuan ilmu pendidikan sains adalah membantu peserta didik mengerti sains itu dengan menggunakan keterampilan yang sesuai dan proses ilmiah untuk mengembangkan kompetensi siswa [1]. Kimia merupakan ilmu sains yang mempelajari materi-materi yang umumnya bersifat abstrak sehingga banyak siswa sulit memahami konsep ilmu kimia. Hal tersebut menyebabkan 
kurangnya hubungan kehidupan nyata dan pengetahuan kimia. Selain itu, dalam ilmu kimia banyak peneliti pendidikan mendapati bahwa kurikulum tidak cukup memberikan hubungan kehidupan nyata dan pengetahuan karena banyak konsep-konsep kimia tidak dipahami dengan baik [2].

Pendekatan berbasis konteks menjadi salah satu cara membangun hubungan kehidupan nyata dan pengetahuan ilmiah [3]. Pendekatan berbasis konteks bertujuan membangun hubungan konteks-konteks isu dunia nyata dan konten ilmiah. Metode pendekatan berbasis konteks membuat siswa aktif, karena keterlibatan penuh siswa dalam belajar, sehingga siswa memahami relevansi kimia dan kehidupan nyata, serta mereka dapat mengembangkan minat yang lebih besar dalam ilmu kimia.

Strategi Relating, Experiencing, Applying, Cooperating and Transferring (REACT) adalah salah satu strategi untuk meningkatkan kemampuan dan hasil belajar siswa. Strategi REACT dapat dilakukan oleh guru, khususnya pada materi yang dekat dengan kehidupan nyata. Strategi REACT memiliki lima tahapan yang harus jelas yaitu Relating, Experiencing, Applying, Cooperating, Transferring. Tahap relating (mengaitkan) adalah pembelajaran dengan mengaitkan materi yang sedang dipelajari dengan konteks pengalaman kehidupan nyata atau pengetahuan yang sebelumnya. Tahap experiencing (mengalami) merupakan pembelajaran yang membuat siswa belajar dengan melakukan kegiatan (learning by doing) melalui eksplorasi, penemuan, pencarian, aktivitas pemecahan masalah, dan laboratorium. Tahap applying (menerapkan) adalah belajar dengan menerapkan konsepkonsep yang telah dipelajari untuk digunakan, dengan memberikan latihan-latihan yang realistik dan relevan. Tahap cooperating (bekerjasama) adalah pembelajaran dengan mengkondisikan siswa agar bekerja sama, sharing, merespons, dan berkomunikasi dengan teman lainnya. Tahap transferring (mentransfer) adalah pembelajaran yang mendorong siswa belajar menggunakan pengetahuan yang telah dipelajarinya ke dalam konteks atau situasi baru yang belum dipelajari di kelas berdasarkan pemahaman [4].

\section{Metode}

Metode penelitian yang digunakan yaitu Quasi Experimen Design dengan desain penelitian Posttest-only Control Group Design [5].

Tabel 1. Rancangan Penelitian

\begin{tabular}{llcc}
\hline Kelas & Sampel & Perlakuan & $\begin{array}{c}\text { Tes } \\
\text { Akhir }\end{array}$ \\
\hline Eks & $\mathrm{R}$ & $\mathrm{X}$ & $\mathrm{O}_{2}$ \\
\hline Kontrol & $\mathrm{R}$ & & $\mathrm{O}_{4}$ \\
\hline Keterangan: & & \\
$\mathrm{R}$ & $=$ Sampel & \\
$\mathrm{X}$ & $=$ Strategi REACT & \\
$\mathrm{O}_{2}$ dan $\mathrm{O}_{4}$ & $=$ Tes akhir (Posttest)
\end{tabular}

\section{Hasil dan Pembahasan}

\section{Hasil Penelitian}

Data yang diperoleh dalam penelitian ini diambil dari dua kelas XI yang ada di SMA Negeri 2 Langowan, yaitu kelas XI IPA 1 dan kelas XI IPA 2. Jumlah siswa yang ada di kelas XI IPA 1 yang merupakan kelas eksperimen berjumlah 25 orang dan jumlah siswa di kelas XI IPA 2 sebagai kelas kontrol berjumlah 21 orang. Data penelitian ini diambil untuk mengetahui efektivitas strategi REACT terhadap hasil belajar siswa dalam mempelajari materi larutan penyangga. Pada penelitian ini data yang diambil adalah hasil belajar siswa yang didapat dari tes akhir (posttest) pada materi larutan penyangga.

a. Data Posttest

Berdasarkan hasil perhitungan data penelitian posttest dari 21 siswa dalam kelas kontrol diperoleh nilai terendah 50 dan nilai tertinggi 80. Skor rata-rata yang diperoleh yaitu 65. Siswa di kelas kontrol yang mencapai KKM adalah 13 orang dan siswa yang tidak mencapai KKM adalah 8 orang. KKM di SMA Negeri 2 Langowan adalah 65. Hasil perhitungan data penelitian posttest dari 25 siswa dalam kelas eksperimen diperoleh nilai terendah adalah 70 dan nilai tertinggi 95. Skor rata-rata yang diperoleh yaitu 83,4. Semua siswa mencapai KKM.

Tabel 2. Hasil Posttest Hasil Belajar Kelas Kontrol dan Kelas Eksperimen

\begin{tabular}{lc}
\hline Kelas & Rata-rata nilai \\
\hline Kontrol & 65 \\
\hline Eksperimen & 83,4
\end{tabular}


b. Uji Normalitas

Uji normalitas ini digunakan untuk mengetahui apakah sampel yang diteliti terdistribusi normal atau tidak. Uji normalitas yang dilakukan dengan menggunakan uji liliefors. Uji normalitas data yang bertujuan untuk mengetahui kenormalan distribusi sebaran skor variabel. Variabel yang diuji adalah variabel terikat (dependen) yaitu hasil belajar siswa dan variabel bebas (independen) yaitu strategi REACT. Untuk mengetahui normalitas dapat digunakan skor signifikan yang ada pada hasil perhitungan uji liliefors bila angka signifikan lebih besar atau sama dengan 0,05, maka terdistribusi normal, tetapi apabila kurang maka data tidak berdistribusi tidak normal [6].

Tabel 3. Hasil Uji Normalitas Posttest Kelas Kontrol \& Kelas Eksperimen

\begin{tabular}{|c|c|c|c|}
\hline \multirow{2}{*}{ Data } & \multicolumn{2}{|c|}{ Posttest } & \multirow{2}{*}{ Kesimpulan } \\
\hline & Eks & Kontrol & \\
\hline $\mathrm{N}$ & 25 & 21 & \multirow{3}{*}{$\begin{array}{l}\text { Lhitung < Ltabel } \\
\text { Data } \\
\text { berdistribusi } \\
\text { Normal }\end{array}$} \\
\hline A & 0,05 & 0,05 & \\
\hline Sig & 0,602 & 0,530 & \\
\hline
\end{tabular}

Berdasarkan tabel 3. hasil uji normalitas posttest, taraf signifikan 0,05 pada kelas eksperimen, diperoleh nilai Lhitung < Ltabel, sehingga $\mathrm{H}_{0}$ diterima, pada data kelas ekperimen berdistribusi normal dan hasil uji normalitas posttest kelas kontrol memperoleh Lhitung < Ltabel, Sehingga $\mathrm{H}_{0}$ diterima pada data kelas kontrol berdistribusi normal. Demikian nilai hasil posttest kelas eksperimen dan kelas kontrol berdistribusi normal.

c. Uji Homogenitas

Uji yang digunakan untuk mengetahui homogenitas data dalam penelitian ini adalah uji-F dengan taraf signifikasi $\alpha=0,05$. Adapun kriteria penerimaan data homogen adalah jika Fhitung $<\mathrm{F}_{\text {tabel, }} \mathrm{H}_{1}$ diterima maka sampel homogen dan jika $F_{\text {hitung }}>F_{\text {tabel, }} \mathrm{H}_{1}$ ditolak maka sampel tidak homogen.

Uji homogenitas ini dilakukan sebagai prasyarat yang kedua dalam menentukan uji hipotesis yang akan digunakan. Demikian dapat dikatakan bahwa $\mathrm{H}_{1}$ diterima $\mathrm{F}_{\text {hitung }}<\mathrm{F}_{\text {tabel }}$ artinya bahwa populasi tersebut memiliki varians yang sama.
Tabel 4. Hasil Uji Homogenitas Posttest Kelas Kontrol dan Kelas Eksperimen

\begin{tabular}{ccc}
\hline Data & Uji-F & Kesimpulan \\
\cline { 1 - 2 } Fhitung $_{\text {Fabel }}$ & 1,74 & $\begin{array}{c}\text { Fhitung }<\mathrm{F}_{\text {tabel, }} \mathrm{H}_{1} \\
\text { diterima }\end{array}$ \\
\cline { 1 - 2 } & 1,98 & fiterim \\
\hline
\end{tabular}

d. Uji Hipotesis

Uji hipotesis dilakukan bertujuan untuk mengetahui peningkatan hasil belajar siswa pada materi larutan penyangga dengan menggunakan strategi REACT. Pada penelitian ini uji hipotesis yang dilakukan yaitu rumus Independent t-test. Pada data nilai post-test dilakukan uji hipotesis dengan menggunakan Uji-t.

Tabel 5. Hasil Pengujian Hipotesis Dengan Uji-t

\begin{tabular}{lcc}
\hline \multirow{2}{*}{ Statistik } & \multicolumn{2}{c}{ Nilai Statistik Posttest } \\
\cline { 2 - 3 } & K. Eks & K.Kontrol \\
\hline Jumlah Responden & 25 & 21 \\
\hline Rata-rata & 83,4 & 65 \\
\hline Varians $\left(\mathrm{s}^{2}\right)$ & 43,1 & 75 \\
\hline thitung & \multicolumn{2}{c}{7,99} \\
\hline tabel & \multicolumn{2}{c}{2,02} \\
\hline Kesimpulan & \multicolumn{2}{c}{ Tolak $\mathrm{H}_{0}$} \\
\hline
\end{tabular}

Pada hasil pengujian hipotesis diperoleh nilai thitung $=7,99$ dan nilai tabel pada taraf signifikan $\alpha=0,05$ adalah 2,02. Berdasarkan hasil tersebut nilai thitung $>$ nilai tabel, maka $\mathrm{H}_{1}$ diterima, Sehingga dapat dikatakan bahwa terdapat peningkatan hasil belajar siswa pada materi larutan penyangga dengan menggunakan strategi REACT. Dengan ini, dapat dikatakan bahwa strategi REACT efektif dalam meningkatkan hasil belajar siswa terlebih khusus pada materi larutan penyangga.

\section{Pembahasan}

Dalam penelitian ini, diketahui bahwa menggunakan strategi REACT efektif dalam meningkatkan hasil belajar siswa kelas XI IPA SMA Negeri 2 Langowan pada materi larutan penyangga. Dalam strategi REACT yang diterapkan pada materi larutan penyangga, siswa melakukan berbagai aktivitas belajar yang berbeda yang tidak diperoleh siswa di kelas kontrol. Strategi REACT terdiri dari lima strategi yang harus tampak pada pembelajaran 
yaitu, relating, experiencing, applying, cooperating, dan transferring.

Strategi REACT diawali relating yaitu dengan memberikan apersepsi, yaitu guru mengarahkan siswa untuk menghubungkan antara konsep yang baru dengan sesuatu yang tidak asing lagi bagi siswa dengan mengajukan pertanyaan-pertanyaan mengenai fenomenafenomena menarik dan sudah tidak asing lagi bagi siswa. Kemudian, strategi relating dilanjutkan dengan pemberian materi secara singkat. Selanjutnya, strategi experiencing adalah pembelajaran yang membuat siswa belajar dengan melakukan kegiatan, sehingga dipilih kegiatan praktikum sederhana untuk membandingkan penambahan asam, basa atau pengenceran terhadap larutan penyangga dan bukan penyangga. Dengan melakukan praktikum sederhana ini siswa dapat membuktikan bahwa larutan penyangga dapat mempertahankan pHnya dan membuktikan kebenaran suatu teori, hal ini yang menjadikan pembelajaran menjadi menarik bagi siswa. Selanjutnya, strategi applying dilakukan dengan memberi latihan soal mengenai materi larutan penyangga yang telah dipelajari, disinilah siswa menerapkan konsep-konsep yang telah dipelajari. Pada strategi cooperating, siswa dikondisikan bekerjasama dalam belajar, strategi ini dilakukan bersamaan dengan strategi experiencing. Selanjutnya siswa mentransfer pengetahuannya ke dalam situasi yang baru yang belum dipelajari di kelas dalam strategi tranferring. Hal ini menyebabkan siswa kelas eksperimen lebih baik hasil belajarnya, karena pemahaman yang diperolehnya berlipat-lipat, dari mengaitkan materi baru dengan pengetahuan yang sebelumnya pada strategi relating, melakukan praktikum untuk membuktikan teori pada strategi experiencing, menerapkan konsep pada strategi applying, bekerjasama dalam belajar dan sharing membahas materi pada strategi cooperating hingga mentransfer pengetahuannya dalam situasi baru pada strategi transferring.

Strategi REACT terdiri dari 5 strategi, terdiri dari banyak aktivitas belajar yang melibatkan siswa secara aktif sehingga siswa dapat memahami suatu materi dengan baik dan menerapkan pengetahuannya lebih dalam daripada siswa kelas kontrol yang diajar dengan model konvensional. Hal ini dapat diamati saat guru menjelaskan materi dengan metode ceramah dan diberikan soal latihan masih banyak siswa kelas kontrol yang berbicara dengan temannya membahas hal lain, sedangkan pada kelas eksperimen siswa hanya diberi penjelasan singkat mengenai materi kemudian melakukan aktivitas belajar lain sehingga siswa dalam belajar lebih serius dan aktif. Pada kelas kontrol diberi pembelajaran dengan model konvensional dengan metode ceramah dan latihan soal sehingga siswa hanya menerima materi dari guru sehingga pembelajaran menjadi monoton dan membosankan sehingga banyak siswa yang tidak aktif dan antusias dalam belajar. Dari penjelasan di atas, dapat diketahui bahwa perlakuan yang berbeda dalam pemberian pembelajaran mengkibatkan hasil belajar siswa kelas kontrol dan kelas eksperimen berbeda.

Murid dapat belajar secara aktif, guru harus memikirkan sebaik-baiknya usaha-usaha apa yang patut dilakukan supaya siswa mempunyai motivasi tinggi untuk belajar [7]. Motivasi yang seperti ini akan dapat tercipta jika guru dapat menciptakan suasana pembelajaran yang menyenangkan dan metode penyampaian yang bervariasi. Adanya praktikum yang merupakan bagian yang tidak terpisahkan dalam strategi pembelajaran REACT mendorong siswa untuk lebih aktif dan antusias dalam mengikuti pembelajaran. Dengan adanya praktikum maka siswa akan tertarik mengikuti pelajaran, karena mereka dapat lebih aktif berfikir dan membuktikan sendiri kebenaran suatu teori [7]. Hal tersebut dapat dijadikan sebagai dasar peningkatan motivasi belajar untuk memahami konsep lebih baik, karena motivasi akan berpengaruh terhadap proses belajar siswa mempelajari suatu materi. Besarnya efektivitas strategi REACT terhadap hasil belajar siswa ditentukan dengan menggunakan Uji-t, dan terbukti dengan $\mathrm{H}_{0}$ ditolak dan $\mathrm{H}_{1}$ diterima, sehingga strategi REACT efektif dalam meningkatkan hasil belajar siswa. Peningkatan hasil belajar ini karena dalam proses pembelajaran siswa kelas eksperimen mengikuti pembelajaran dengan penggunaan strategi REACT yang terdiri dari berbagai aktifitas belajar yang beragam dibandingkan kelas kontrol yang diajarkan dengan model 
konvensional yang terdiri dari metode ceramah dan latihan soal. Strategi REACT adalah strategi dari pembelajaran kontekstual sehingga siswa dapat mengaitkan antara materi yang dipelajari dengan kehidupan sehari-hari serta melatih kerjasama siswa terhadap teman sekelompoknya. Hal ini ditunjukkan pada saat pembelajaran siswa terlihat antusias, siswa cenderung lebih aktif bertanya pada teman maupun guru. Siswa yang belajar secara individu biasanya tidak meningkat sebanyak siswa yang belajar secara berkelompok [8].

Pengujian validasi instrumen tes diberikan pada siswa yang telah mempelajari materi larutan penyangga dalam hal ini kelas XI IPA yang berjumlah 25 orang. Instrumen tes yang divalidasi terdiri dari 5 butir soal essay. hasil uji validasi terdapat 4 butir soal yang valid dan 1 butir soal yang tidak valid. Maka, soal yang digunakan adalah 4 soal.

Pada pengujian hipotesis nilai thitung $(7,9996)$ $>$ nilai tabel $(2,018)$ dengan demikian penerapan strategi REACT efektif dalam meningkatkan hasil belajar siswa kelas XI IPA SMA Negeri 2 Langowan. Hasil penelitian menunjukkan bahwa penerapan strategi REACT berpengaruh positif terhadap hasil belajar siswa. Hal ini sejalan dengan penelitian sebelumnya tentang pengaruh penerapan pembelajaran kimia dengan strategi REACT terhadap hasil belajar siswa kelas XI MAN Babakan Lebaksiu Tegal yang menunjukan bahwa pembelajaran dengan strategi REACT memberi pengaruh sebesar 20,25\% terhadap hasil belajar kimia siswa [9].

\section{Kesimpulan}

Berdasarkan analisis data hasil belajar siswa kelas kontrol dan kelas eksperimen di SMA Negeri 2 Langowan pada materi larutan penyangga, maka dapat disimpulkan bahwa metode pembelajaran CTL (Contextual Teaching and Learning) menggunakan strategi REACT (Relating, Experiencing, Applying, Cooperating, Transferring) terbukti efektif terhadap peningkatan hasil belajar siswa kelas XI IPA SMA Negeri 2 Langowan pada materi larutan penyangga

\section{Daftar Pustaka}

1. Ceylan, E., Effects of 5E learning cycle model on understanding of state of matter and solubility concepts. Unpublished Doctor Thesis, Orta Dogu Teknik University, Institute of Science and Technology, Ankara 2008.

2. Gilbert, J. K., On the nature of "context" in chemical education. International journal of science education 2006, 28, (9), 957-976.

3. Schreiner, C.; Sjøberg, S., Science education and youth's identity construction-two incompatible projects? In The re-emergence of values in science education, Brill Sense: 2007; pp 231-247.

4. Crawford, M. L., Teaching contextually. CCI: Texas, 2001.

5. Sugiono, Metode Penelitian Kuantitatif, Kualitatif, dan Kombinasi (Mixed Methods). Alfabeta: Bandung, 2013.

6. Azwar, S., Reliabilitas dan Validitas. Pustaka Pelajar: Yogyakarta, 2011; p 381.

7. Hamdani, Strategi Belajar Mengajar. Pustaka Setia: Bandung, 2011.

8. Davtyan, R. In Contextual learning, ASEE 2014 Zone I Conference, 2014; pp 3-5.

9. Farid, A.; Nurhayati, S., Pengaruh Penerapan Strategi REACT terhadap Hasil Belajar Kimia Siswa Kelas XI. Chemistry in Education 2014, 3, (1). 